\title{
The Industrial Revolution 4.0 Impact on Vocational Education in Indonesia
}

\author{
Setiyawami ${ }^{1}$, Sugiyo ${ }^{2}$, Sugiyono ${ }^{2}$, Tri Joko Rahardjo ${ }^{2}$ \\ \{setiyawami@uny.ac.id ${ }^{1}$ \} \\ ${ }^{1}$ Post Graduate Student Universitas Negeri Semarang, Indonesia \\ ${ }^{2}$ Post Graduate Universitas Negeri Semarang, Indonesia
}

\begin{abstract}
Indonesia, especially in vocational education, namely vocational schools. The demand for vocational education in vocational schools is increasingly large and global, in addition to having the function of creating human resources with special skills, and also being able to balance with technological developments in the 4.0 era. This study aims to analyze the impact of the industrial revolution 4.0 on vocational education in Indonesia. The method used is literature review. The results of this study indicate that, the impact of the industrial revolution 4.0 is strongly felt by vocational education in Indonesia today, where vocational education is still unable to answer the challenges of current technological developments, by creating high levels of employment for its graduates. The positive impact is the role of vocational education, namely vocational schools, to be able to balance the skills that are currently developing, as well as the quality of teacher competencies based on ideal standards. the conclusion of this study, the impact of the industrial revolution 4.0 for education, must be seen from the many positive sides. Domain and concept adjustments, so that they are aligned with dynamic changes in skills, and teacher competencies, must be based on professional quality standards.
\end{abstract}

Keywords: industrial revolution 4.0; vocational education; teacher competences

\section{Introduction}

Since the term industry revolution 4.0 emerged, accompanied by various phenomena. Industry 4.0 is characterized by an increase in digitalization of manufacturing driven by four factors: 1) an increase in data volume, computational power, and connectivity; 2) the emergence of analysis, capabilities, and business intelligence; 3) the occurrence of new forms of interaction between humans and machines; and 4) improvement of digital transfer instructions to the physical world, such as robotics and 3D printing [1]. The machine will operate independently or coordinate with humans [2], in other words, the mechanism of work is more oriented to the machine compared to human power.

Industry 4.0 is an approach to control the production process by synchronizing time by integrating and adjusting production [3]. Industry 4.0 was used on three interrelated factors namely; 1) digitization and interaction of economics with simple techniques towards economic networks with complex techniques; 2) digitalization of products and services; and 3) new market models . One of the unique characteristics of Industry 4.0 is the application of artificial intelligence [4]. One form of application is the use of robots to replace human 
labor so that they are cheaper, more effective and efficient. Technological advancements make automation possible in almost all fields. New technologies and approaches that combine the physical, digital and biological world will fundamentally change the patterns of life and human interaction.

Wolter identified the challenges of industry 4.0 as follows; 1) information technology security issues; 2) the reliability and stability of the production machine; 3) lack of adequate skills; 4) unwillingness to change by stakeholders; and 5) the loss of a lot of work because it turns into automation [2]. He simplifies industry 4.0 challenges namely; (1) industry readiness; (2) trusted workforce; (3) ease of socio-cultural regulation; and (4) diversification and job creation and industry opportunities 4.0 namely; (1) ecosystem innovation; (2) competitive industrial base; (3) investment in technology; and (4) integration of Small and Medium Enterprises (SMEs) and entrepreneurship [5].

Mapping the challenges and opportunities of industry 4.0 to prevent various impacts on people's lives, one of which is the problem of unemployment. Work Employment and Social Outlook Trend 2017 predicts the number of unemployed people globally in 2018 is expected to reach 204 million with an additional increase of 2.7 million. Almost the same as the conditions experienced by western countries. including Indonesia Indonesia's open unemployment rate in February 2017 was $5.33 \%$ or 7.01 million of the total 131.55 million workforce [6].

BPS also shows, the number of unemployed people who came from Vocational High Schools (SMK) was in the top rank of $9.27 \%$, graduates of High Schools (SMA) by $7.03 \%$, Diploma III (D3) by $6.35 \%$, and university $4.98 \%$. The factor influencing the lack of interest in vocational education in Indonesia, which is balanced with the development of industry in the 4.0 era, is the conventional majors factor. [7] added that vocational training and skill acquisition greatly influence the development of a person's identity related to work. Another factor is that the quality of education in vocational schools is still low, [8]. The low quality of vocational education, is suspected by (a) Not being able to develop the potential / nature of students optimally; (b) Have not been able to organize a Fun Teaching and Learning Activity (KBM); and (c) Has not been able to produce graduates who have moral integrity.

The challenges and opportunities of the industrial revolution 4.0 drive the acceleration of innovation and the creation of vocational education. This study aims to analyze the impact of changes in the industrial era 4.0, on vocational education (SMK) in Indonesia, and analyze the revitalization efforts that should be undertaken so that vocational education (SMK) is not reduced by the impact of industrialization in the 4.0 era. and appropriated teachers competences in vocational schools.

\section{Research method}

This study uses a literature review, focusing on the challenges in vocational schools on changes in industrialization in the 4.0 era. The data used in this research is secondary data. Secondary data is data obtained from the results of research that has been done by previous researchers. The secondary data sources referred to are primary and original books and scientific reports contained in articles or journals (printed and / or non-printed). The data used is related to the theme, skills in the 21 st century. Data analysis uses annotated bibliography. Research procedures with the organization of articles from journals and books, which are relevant to the theme, synthesize the findings of the article, identify ideas that are considered important, and formulate data that is used as the essence of research.

\section{Result and Discussion}




\section{a. Adjustment of vocational education (SMK) to the industrial revolution 4.0}

21 st century learning is oriented towards digital lifestyle, thinking tools, learning research and the workings of knowledge, therefore, vocational education requires a high level of literacy [9]. The theme of information literacy is (1) determining the nature and level of information needs needed, (2) accessing the information needed, (3) using information effectively and efficiently, (4) using ethical and legal information [10], and (5) critically evaluate information and sources and incorporate selected information into pre-existing knowledge and value systems [11] (1) identify sources of information; (2) identify types of information; (3) choosing how to access information through the internet; (4) rediscovering information online; (5) establish criteria for assessing information from the internet; (6) establish criteria for assessing information from books; (7) uses new information to plan and create results; (8) communicating results or performance in writing; (9) understand various ethical, legal and socio-economic issues around information and information technology; and (10) recognizing the use of information sources used [12].

Based on Permendikbud (regulation) No. 23 of 2017 concerning School Days, there are several things that are strengthened from the 2013 Curriculum results of the 2017 revision, namely (1) strengthening of character education, (2) mastery of literacy, and (3) strengthening of high order thinking or high order thinking skills. While the character is focused on aspects of religiosity, nationalism, independence, mutual cooperation and integrity. In literacy mastery is emphasized in the 21 st century literacy that is summarized in $4 \mathrm{C}$, namely (1) creative, (2) critical thinking, (3) communicative and (4) collaborative. These $4 \mathrm{C}$ aspects include some high-level thinking competencies.[13].

Thus, learning in the 4.0 era focuses on the formation of IT-based digital lifestyles, the ability and innovation of learning, and the development of life skills, and more specifically, learning undertaken by teachers must be oriented towards developing four core skills: critical thinking skills and problem solving, communication skills, collaboration skills, and the ability to create new things (creativity), [9].

Revitalizing the learning system includes, 1) curriculum and character education, 2) learning materials based on information and communication technology, 3) entrepreneurship, 4) alignment, and 5) evaluation. Education units include, 1) new school units and new classrooms, 2) other learning rooms, 3) classroom rehabilitation, 4) student and teacher dormitories, 5) equipment, and 6) school management and culture. Elements of students include, 1) scholarships and 2) talent development of interest. Elements of educators and education personnel include, 1) provision, 2) distribution, 3) qualifications, 4) certification, 5) training, 6) career and welfare, and 7) appreciation and protection.

The number of unemployed SMK graduates had made the government take a policy to revitalize vocational education [6]. There are four points that become the focus of revitalization of SMK which is mandated in Presidential Instruction no. 9 of 2016. These four points include curriculum revitalization, educators \& education personnel, cooperation, and graduates. (1). Curriculum; The curriculum is currently rigidly assessed. As a result, it is difficult to meet the needs of the workforce that is ready for business and industry. (2). Educators \& labor; In addition to availability, revitalization is also aimed at improving teacher competence [14].

\section{b. Ideal Vocational Teacher competencies}

The teacher competencies are: (1) Competency exists in a real-life setting, (2) Competency follows a progression from simple to complex, (3) Competency is based on a set of resources, (4) Competency is based on the ability to mobilize resources in situations requiring professional action, (5) Competency is part of intentional practice, (6) Competency is demonstratedas a successful, effective, efficient, recurrent performance, (7) Competency is a project, an ongoing pursuit. 
Therefore, based on The World Economic Forum warns structural changes in skills in the 21 st century. In 2015, the structure of skills needed by the workforce is as follows; 1) complex problem solving; 2) cooperation with others; 3) people management; 4) critical thinking; 5) negotiation; 6) quality control; 7) service orientation; 8) assessment and decision making; 9) active listening ; and 10); creativity. In 2020 the work structure changes to; 1) complex problem solving; 2) critical thinking; 3) creativity; 4) people management; 5) cooperation with others 6) emotional intelligence; 7) assessment and decision making; 8) service orientation; 9) negotiation; and 10) cognitive flexibility.

Thus, the skills of vocational teachers in the 4.0 era, namely: leadership, collaboration, creative, digital literacy, effective communication, emotional intelligence, entrepreneurship, global citizens, problem solving and teamwork, and have supporting skills, namely: critical thinking, creativity and innovation, cross-cultural understanding, information and media literacy, career and learning skills.

\section{Conclusion}

The impact of the industrial revolution 4.0 on education must be seen from the many positive aspects. Domain, and concept adjustments, to be aligned with dynamic changes in skills, and teacher competencies, must be based on professional quality standards, so that there is compatibility between domains in the 4.0 era.

\section{References}

[1] Lee, J., Lapira, E., Bagheri, B., Kao, H., "Recent Advances and Trends in Predictive Manufacturing Systems in Big Data Environment.," Manuf. Lett, vol. 1, no. 1, pp. 38 41, 2013.

[2] T. K. Sung, "Industri 4.0: a Korea perspective.," Technol. Forecast. Soc. Chang. J., pp. 1-6, 2017.

[3] J. . Kohler, D, \& Weisz, Industry 4.0: the challenges of the transforming manufacturing. Germany: BPIFrance, 2016.

[4] R. . Tjandrawina, "Industri 4.0: Revolusi industri abad ini dan pengaruhnya pada bidang kesehatan dan bioteknologi," J. Med., vol. 29, no. 1, 2016.

[5] D. Irianto, "Industry 4.0; The Challenges of Tomorrow," in Seminar Nasional Teknik Industri, Batu-Malang, 2017.

[6] Badan Pusat Statistik (BPS), Keadaan Ketenagakerjaan Indonesia Nopember 2016. 2016.

[7] F. Brown, A., Kirpal, S., \& Rauner, Identitas at work. Springer, 2007.

[8] K. D. Deal, T. E \& Peterson, Shaping school culture: the heart of leadership. San Francisco: Jossey-Bass Publisher, 1999.

[9] C. Trilling, B \& Fadel, 21st-century skills: learning for life in our times. US: JosseyBass A Wiley Imprint., 2009.

[10] and I. K. Y. A. N. Çoklar, N. D. Yaman, "Information literacy and digital nativity as determinants of online information search strategies," Comput. Hum. Behav, 2017.

[11] G. Shao, X., \& Purpur, "Effects of Information Literacy Skills on Student Writing and 
Course Performance,” J. Acad. Librariansh., vol. 42, no. 6, pp. 670-678, 2016.

[12] I. H. S. Hasan Subekti, Mohammad Taufiq, Herawati Susilo, "Mengembangkan Literasi Informasi Melalui Belajar Berbasis Kehidupan Terintegrasi Stem Untuk Menyiapkan Calon Guru Sains Dalam Menghadapi Era Revolusi Industri 4.0: Revieu Literatur," Educ. Hum. Dev. J., vol. 3, no. 1, 2018.

[13] H. Ibda, "Urgensi Pemertahanan Bahasa Ibu di Sekolah Dasar," J. SHAHIH, vol. 2, no. $2,2017$.

[14] Yoto, "Pengembangan Pendidikan Kejuruan Melalui Pendidikan dan Pelatihan Bidang teknik Mesin Bagi Guru SMK,” J. Tek. Mesin, vol. 23, no. 1, 2015. 